\title{
Camellia sinensis (Green Tea) Mediated Synthesis of Zinc Oxide Nanoparticles and Detect its Antibacterial Activity against Escherichia coli, Staphylococcus aureus and Acinetobacter baumannii
} الثاي الاخضر كوسيط لتصنيع دقائق اوكسيد الزنك النانوية والتحري عن فعاليته المضادة لبكتريا Staphylococcus aureus, Escherichia coli, and Acinetobacter baumannii

\author{
Israa Ali Zaidan Al-Ogaidi \\ Department of Biotechnology/ College of Science/ Baghdad University

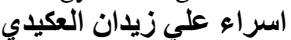 \\ قسم التقنيات الاحيائية/ كلية العلوم/ جامعة بغداد العيداد
}

E-mail: biotechphd2011@yahoo.com

\begin{abstract}
In the current study, synthesis and characterization of Zinc oxide nanoparticles (ZnONPs) and its application as anti-pathogenic bacteria were investigated. $\mathrm{ZnO}$ which has been prepared by using aqueous of green tea leaves extract (Camellia sinensis) as a reducing agent. The wavelength range was measured by Ultraviolet-visible spectroscopy (UV-Vis) for monitoring the formation of the nanoparticles, which showed sharp peak at $360 \mathrm{~nm}$. The average size and shape of the nanoparticles were detected by using Atomic Force Microscopy (AFM) which was 88 nm with spherical shape. Fourier transform-infrared (FTIR). FT-IR spectra was documented for the ZnO nanoparticles synthesized by green tea extract to detect the biomolecules involved in the synthesis process. The antibacterial activity of crystal Zinc Oxide $(\mathrm{ZnO})$ nanoparticles was explored against pathogenic bacteria that included Escherichia coli, Staphylococcus aureus, and Acinetobacter baumannii. The antibacterial test was conducted in solid media using different concentrations of $\mathrm{ZnO}$ and disk diffusion method, $100 \mu \mathrm{g} / \mathrm{ml}$ presented the best antibacterial activity, and further studies on the damage of bacterial genomic DNA of Escherichia coli and Acinetobacter baumannii were carried out using gel electrophoresis exposed the DNA fragment bands, this activity may be caused by the interactions between the surface charge of cell and nanoparticles. Reactive oxygen species (ROS) properties of the particles might disturb cell wall and great antimicrobial action
\end{abstract}

Key words: Nanoparticles, Zinc oxide, Pathogenic bacteria, DNA damage

$$
\begin{aligned}
& \text { الملخص المص } \\
& \text { هدف البحث اللى دراسة تأثير دقائق اوكسد الزنك النانوية المحضرة بطريقة المستخلص المائي لاوراق الشاي الاخضر كمضاد بكتيري }
\end{aligned}
$$

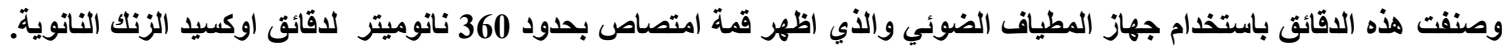

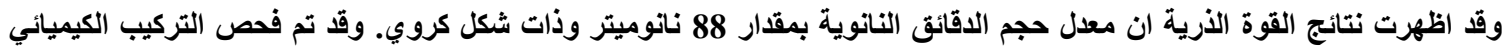

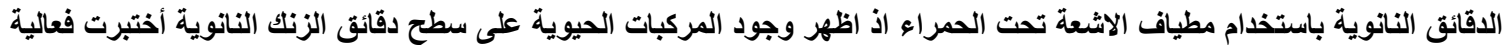

$$
\begin{aligned}
& \text { Staphylococcus aureus Acentobacter baumannii, دقائق اوكسيد الزنك المصنعة كمضادات لثلاثة انواع بكتيرية هي }
\end{aligned}
$$

\section{Introduction}

In the recent years different bacterial strains have developed resistance to conventional antimicrobial drugs, such strains include multi-drug-resistant isolates of Staphylococcus aureus, Acinetobacter baumanii and Escherchia coli [1]. The rapid spread of these isolates and the dangerous infections caused by them require the urge to find the replacement for the treatment of these MDR isolates derived the medical community to use them as novel antimicrobial agents. These new replacements must have the ability to interact and block microbial targets [2]. Silver and zinc oxide nanoparticles recently used as antibacterial agents, the mechanism of action of Ag NPs summarized by; Ag ions are released in aqueous solutions which cause the antimicrobial effect [3]. The exact mechanism of $\mathrm{ZnO}$ is yet unknown but it has been proven that the nanoscale $\mathrm{ZnO}$ has more antimicrobial activity than microscale $\mathrm{ZnO}$ and the smaller 
concentration have better activity [4]. However; silver and zinc oxide NPs have a toxic effect on the prokaryotic and eukaryotic cells and have a damaging effect on the DNA [3,5]. ZnO nanoparticles can be synthesized using different chemical, physical and biological methods [6]. The biological techniques, using plant extract, microorganisms and enzymes, have been recommended as possible eco-friendly replacements [7]. The benefits of using plant or plant extract as reducing and coating agents during synthesizing nanoparticles is the preferred one over other biological methods, other biological methods, because it is a one-step biosynthesis process, shorten the long process of culturing and preserving of the cell, safe for human therapeutic use, and can also be scaled up for synthesis of large-scale nanoparticles. Many approaches are engaged for the synthesis of silver nanoparticles including reduction silver nitrate in solutions; microwave assisted, laser ablation, and biological or green synthesis methods [6, 8]. The latter is the most favorite ecofriendly fast method for synthesizing nanoparticles [9]. The current study differs from previous reports by using the green method instead of chemical method to synthesis ZnONPs. This study aims to use nanomaterials to achieve antibacterial activity against MDRs isolates through testing the activity of $\mathrm{ZnO}$ against MDRs isolates and test its ability to damage DNA of Escherichia coli and Acinetobacter baumannii.

\section{Materials and Methods Synthesis ZnO Nanoparticles}

Zinc acetate dihydrate with $90 \%$ purity was perused from sigma and distilled water was utilized through all the experiments. $0.2 \mathrm{M}$ of zinc acetate dehydrate was dissolved in $70 \mathrm{ml}$ of distilled water and mixed for few minutes. Five gm of dried form of green tea leaf was added to $100 \mathrm{ml}$ of distilled water and kept stir for $2 \mathrm{~h}$ at $80^{\circ} \mathrm{C}$ by magnetic stirrer. Later on, the extract was kept to cool at room temperature and separated using filter paper (whatman No. 1); zinc acetate dihydrate then mixed with $30 \mathrm{ml}$ of green tea extract. Finally the solution was dried at $60{ }^{\circ} \mathrm{C}$ in vacuum oven overnight to yield pale-white $\mathrm{ZnO}$ nanoparticles [10].

\section{Characterizations of $\mathrm{ZnO}$ Nanoparticles}

The maximum wavelength of UV-Vis (PD-303, Apel, Japan) absorption was ranged between 200-1200 $\mathrm{nm}$ to estimate the diameter and the shape of the $\mathrm{ZnO}$. The shape and size of nanoparticles were analyzed by Atomic Force Microscopy (AFM) (Park Systems, Suwan, South Korea). Fourier transform-infrared (FTIR) spectra of the samples were recorded using FTIR (8400S Shimadzu / Japan).

\section{Antibacterial Activity of the ZnO Nanoparticles}

Three kinds of multi drug resistance bacteria were provided for this study from department of biotechnology -College of science/ Baghdad University, which were Escherichia coli, Acinetobacter baumannii and Staphylococcus aureus. To determine the antibacterial activity of $\mathrm{ZnO}$ nanoparticles the earlier mentioned bacteria cultivated separately in Luria-Bertani (LB ) medium that prepared by adding $4.0 \mathrm{~g}, 2.0 \mathrm{~g}$, and $5.0 \mathrm{~g}$ from peptone, yeast extract and $\mathrm{NaCl}$ respectively to $400 \mathrm{~mL} \mathrm{H}_{2} \mathrm{O}$ with $\mathrm{pH}$ value 7.2-7.5 and $1 \mathrm{~mol} \mathrm{~L}^{-1}$ of $\mathrm{NaOH}$ before autoclaving. For producing $\mathrm{LB}$ agar $6.8 \mathrm{~g}$ of the agar is added to $1 \mathrm{~L}$ of LB medium. The activity of ZnONPs against Staphylococcus aureus, E. coli and A.baumannii were evaluated by disc diffusion method. Briefly, impregnated $6 \mathrm{~mm}$ well with different concentrations of $\mathrm{ZnONPs}$ which were $25,50,75$, and $100 \mu \mathrm{g} / \mathrm{ml}$. Inhibition zones were checked after $24 \mathrm{~h}$ at $37^{\circ} \mathrm{C}$ incubation $[11,12]$.

\section{Effect of ZnONPs on the DNA of Bacteria}

E. coli and A.baumannii were incubated with the appropriate concentration of $\mathrm{ZnO}$ nanoparticles. After 24 hours, DNA was extracted by using Exiprep instrument with DNA extraction kit provided by Bioneer (Korea). Yield and purity of DNA samples were estimated by using nanodrop, and the quantity of extracted DNA was estimated by DNA electrophoresisis performed in $1 \%$ agarose gel holding $10 \mu \mathrm{g} / \mathrm{mL}$ ethidium bromide at $70 \mathrm{~V}$, and the DNA fragments were observed by exposing the gel to ultraviolet light and documented by gel documentation [13].

\section{Results and discussion}

Producing nanoparticles by eco-friendly methods has recently become a hot topic of research, because of the growing applications in the biomedical areas. Various environmentally friendly and biological methods of $\mathrm{ZnO}$ nanoparticles synthesis have recently been reported $[14,15]$. Meanwhile, decreasing the problem 
of multidrug resistance bacteria becomes more important these years [16]. Herein, $\mathrm{ZnO}$ NPs were synthesized in the presence of green tea extract. The green tea extracts contains catechins and flavanols [17] which serve as reducing agents for the zinc acetate to $\mathrm{ZnO}$ nanoparticles. These bioorganic contents also serve as capping agents during the nanoparticle synthesis [18]. The mechanisms of action of the bioorganic molecules have been reported to provide a good activity giving the ability to stimulate the reduction precursor of nanomaterial in the formation of nanoparticles [19]. Phenolic composite shows great antioxidant agent and this property is a very good to reduce metal particles, consequently supporting the green synthesis of nanoparticles. Furthermore, higher substance of proteins, lipids and amino acids help the development of nanoparticles and prevent molecule agglomeration [20].

At the end of the ZnONPs synthesis, the presences of nanoparticles were detected through the UV-vis spectra. The absorbance peak was recorded at $360 \mathrm{~nm}$ in Figure (1). The green tea leaf extract reduction of the zinc acetic dehydrates to $\mathrm{ZnO}$ nanoparticles were produced as a powder with a pale white color. During synthesis, the addition of the tea extracts was accompanied by an immediate change in color which indicated the start of the formation of the ZnONPs. The color of the reaction went from colorless to white color; the color change indicates the formation of $\mathrm{ZnO}$ nanoparticles as confirmed by the UV-vis spectra. In Figure (1), the spectra showed a pronounced peak around $360 \mathrm{~nm}$ which had been previously reported for the synthesis of ZnONPs [21]. The highly blue-shifted absorption maximum occurring around $360 \mathrm{~nm}$ confirms the formation of $\mathrm{ZnO}$ product in nanoscale, because the absorption maximum for the bulk $\mathrm{ZnO}$ occurs at about $385 \mathrm{~nm}$ [11].

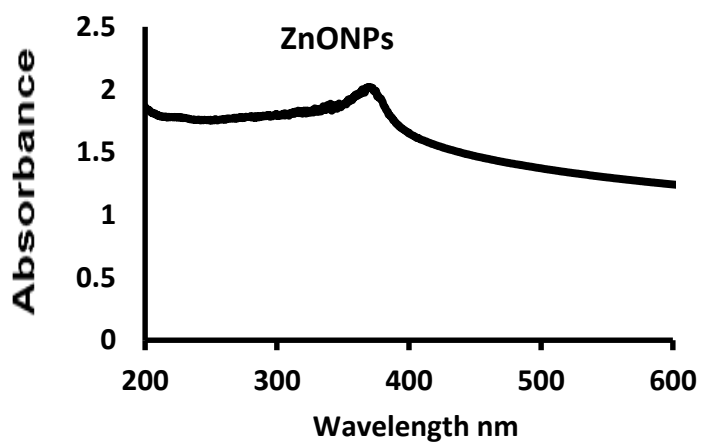

Fig. (1): UV-Vis spectrum of synthesized ZnO NPs by green tea.

Figure (2) presents the FTIR spectra of the $\mathrm{ZnO}$ nanoparticles synthesized by green tea, which illustrated the composition and quality of the product. FTIR spectroscopy estimate the retention of IR radiations by a sample plotted against the wavelength. The interpretation of the IR range includes the relationship of the absorption bands (vibrational groups) with the chemical composites in the sample [22]. Along these lines, the biomolecules present in plant extract that were served as of the reduction and capping agent in events of the green synthesis of nanoparticles can be recognized.

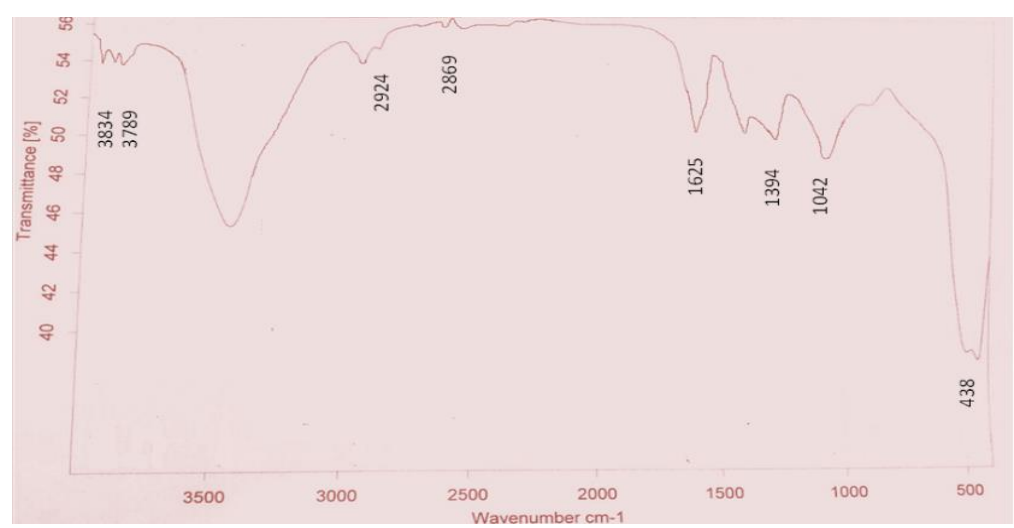

Fig. (2): FT-IR spectra of ZnO NPs synthesized by green tea. 
In the IR range of green tea, the band around $3000 \mathrm{~cm}^{-1}$ because of extending vibrations of $\mathrm{O}-\mathrm{H}$ group in water, alcohol and phenols and $\mathrm{N}-\mathrm{H}$ extending in amines. The $\mathrm{C}-\mathrm{H}$ stretch in alkanes and $\mathrm{O}-\mathrm{H}$ stretch in carboxylic corrosive show up at 2924 and $2869 \mathrm{~cm}^{-1}$ individually. The band at $1625 \mathrm{~cm}^{-1}$ was ascribed to the $\mathrm{C}=\mathrm{C}$ stretch in fragrant ring and $\mathrm{C}=\mathrm{O}$ stretch in polyphenols. The $\mathrm{C}-\mathrm{N}$ stretch of amide-I in protein gives the band at $1394 \mathrm{~cm}^{-1}$. The $\mathrm{C}-\mathrm{O}$ extending in amino corrosive causes a band at $1042 \mathrm{~cm}^{-1}$. At long last the powerless band at $820 \mathrm{~cm}^{-1}$ is the after effect of $\mathrm{C}-\mathrm{H}$ out of plane bend [22]. In this manner from the IR range it can be observed that green tea test was rich in polyphenols, carboxylic corrosive, polysaccharide, amino corrosive and proteins. The presence of the phenol may work as a good reducing agent and amide group in protein was responsible for the stabilization $\mathrm{ZnO}$ nanoparticles, the peak showing up at $438 \mathrm{~cm}^{-1}$ can attributed of $\mathrm{ZnO}$ molecules [22,23]. The surface morphology and size range of the $\mathrm{ZnO}$ nanoparticles were measured by AFM. The two-and three-dimensional geography of the $\mathrm{ZnO}$ nanoparticles was presented in Figure (3A) direct observation of the image exposed spherical shape of $\mathrm{ZnO}$ nanoparticles. The size distribution of the $\mathrm{ZnO}$ particles were showed in Figure (3B) which were in the range of 50-140 nm, and it clearly showed that most of the $\mathrm{ZnO}$ nanoparticles were at $88 \mathrm{~nm}$ sizes. This construction of $\mathrm{ZnO}$ NPs was produced during the reduction process by green tea extract that lead to nucleation of $\mathrm{ZnO}$ nanoparticles.
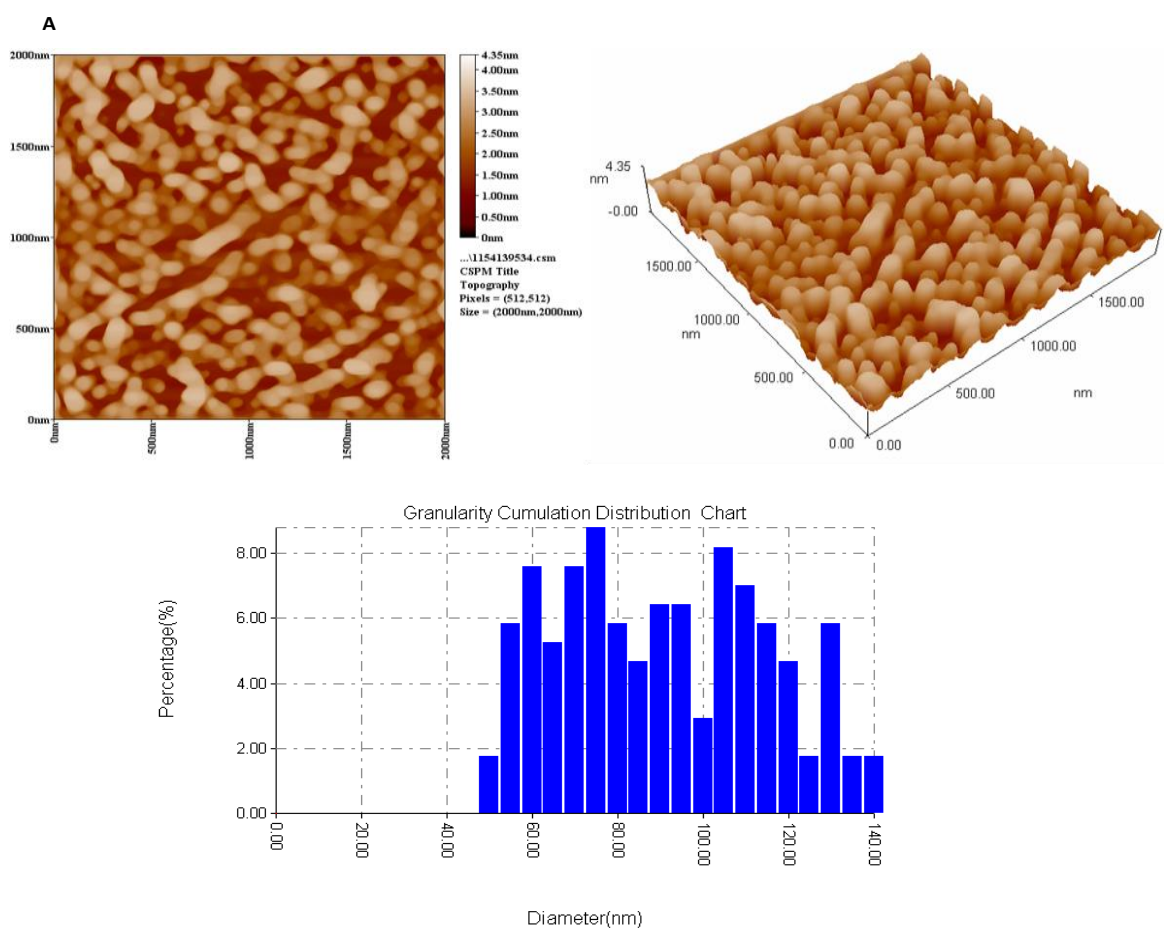

Fig. (3): AFM characterization of $\mathrm{ZnO}$ nanoparticles. (A) Surface morphology (B) chart for granularity distributed $\mathrm{ZnO}$ of nanoparticles

In this study ZnONPs showed remarkable antibacterial action against gram positive and negative bacteria even at low concentration as shown in Table (1). Based on the different in the bacterial structure the activity of $\mathrm{ZnO}$ on the gram positive bacteria was more than its activity on gram negative bacteria, because the interaction between nanoparticles and cell surfaces would be differ that lead to effect on the penetrability of membranes, since the entrance of nanoparticles inside bacterial cell induce oxidative stress consequently leading to inhibit cell growth and ultimately cell death $[13,21,24]$. There was a significant effect on S.aureus bacteria than on both the E.coli and A.baumanii bacteria. These results agree with the early study that reported the stronger antibacterial effect of $\mathrm{ZnO}$ on gram positive bacteria than gram negative bacteria [12]. The mechanism of action of $\mathrm{ZnO}$ nanoparticles was still unidentified; however, the predicted action that $\mathrm{ZnO}$ could adhere to the cell surface and caused damaged of the cell membrane or they can electrostatically interact with the surface of the cell [25-28]. Moreover, the activity of metal oxides could produce oxygen species like reactive oxygen species (ROS); at high levels ROS can diminish the physiological function of cell through diminishing cellular proteins, lipids, damage of DNA and further macromolecules [29-31]. 
Table (1): Zone of inhibition of antibacterial test of $\mathrm{ZnO}$ nanoparticles

\begin{tabular}{ccccc}
\hline Bioactive agent & $\begin{array}{c}\text { Concentration } \\
\mu \mathrm{g} / \mathrm{ml}\end{array}$ & zone of inhibition $[$ Diameter, $\mathrm{mm}]$ & \\
\hline \multirow{4}{*}{ ZnO NPs } & & E.coli & aureus & baumannii \\
& 25 & 0 & 0 & 0 \\
& 50 & 11 & 14 & 6 \\
& 75 & 15 & 19 & 8 \\
\end{tabular}

To investigate the effect of ZnONPs on the genomic DNA of E. coli and A.baumannii, different concentrations of $\mathrm{ZnO}$ nanoparticles were tested. These isolates were evaluated by agarose gel electrophoresis as shown in Figure (4). The results were revealed destructive effects of $\mathrm{ZnO}$ on the genome of bacteria. It was clearly showed that there were single bands for chromosome and plasmids for normal E. coli and A. baumannii cell while DNA of E. coli and A. baumannii treated with $\mathrm{ZnO}$ was fragmented showing the evidence of action of nano- $\mathrm{ZnO}$ particle effect on the DNA damage thereby increasing antibacterial activity and these results are comparable with Prasad et al., [13] investigation.

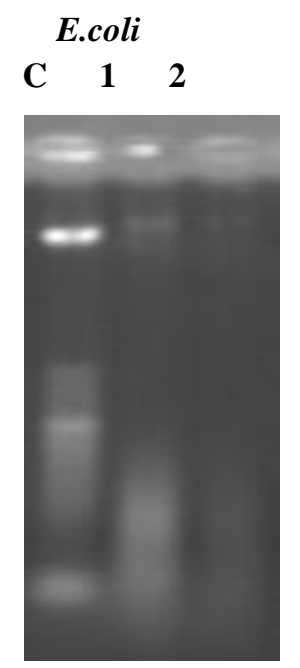

\section{A.baumannii}
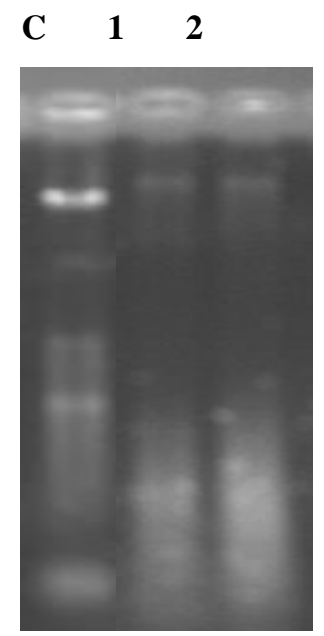

Fig. (4): The amount of DNA from normal $E$. coli and A.baumannii cells and bacterial cells treated by nano ZnO on agarose gel C: control, 1: $50 \mu \mathrm{g} / \mathrm{ml} \mathrm{ZnO,} \mathrm{2:} 100 \mu \mathrm{g} / \mathrm{ml}$.

\section{Conclusion}

From the current investigation successful preparation of $\mathrm{ZnO}$ by economically method using leave extract of green tea. $\mathrm{ZnO}$ is achieved andcharacterized by UV-vis, FTIR and AFM. The FTIR studies obviously indicated the capping and reduction biomolecules being in the leave extract of green tea, the presence of high amount of biomolecules was responsible for the reduction process and the amino acids and amide bonds in protein were worked as stabilizer agents of the $\mathrm{ZnO}$ nanoparticles. The antibacterial tests demonstrated that $100 \mu \mathrm{g} / \mathrm{ml}$ was the best antibacterial activity and the integrity of bacterial DNA was affected after treated with ZnONPs. The results have shown a destructive effect on DNA resulting in DNA degradation, therefore, inhibiting growth of bacteria. Hence conclude that using of $\mathrm{ZnO}$ nanoparticles can help in treating pathogenic bacteria and can be additionally used as potential production agent against bacteria

\section{References}

1. Cassir, N. Rolain, J.M. and Brouqui, P. (2014). A new strategy to fight antimicrobial resistance: The revival of old antibiotics. Front. Microbiol. 5, 551.

2. Rai, M.K., Deshmukh, S.D., Ingle, A.P. and Gade, A.K. (2012). Silver nanoparticles: The powerful nanoweapon against multidrug-resistant bacteria. J. Appl. Microbiol. 112, 841-852. 
3. Stiufiuc, R., Iacovita, C., Lucaciu, C.M., Stiufiuc, G., Dutu, A.G., Braescu, C. and Leopold, N. (2013). SERS active silver colloids prepared by reduction of silver nitrate with short-chain polyethylene glycol. Nanoscale Res. Lett. 8.

4. Hong, R.Y., Li, J.H., Chen, L.L., Liu, D.Q. and Li, H.Z., Zheng, Y. (2009). Synthesis, surface modification and photocatalytic property of ZnO nanoparticles. Powder Techno. 189:426-32.

5. Umar, A., Rahman, M.M., Vaseem, M. and Hahn, Y.B. (2009). Ultra-sensitive cholesterol biosensor based on low-temperature grown $\mathrm{ZnO}$ nanoparticles. Electrochem Commun.11:118-21.

6. Sahoo, S.K., Parveen, S. and Panda, J.J. (2007). The present and future of nanotechnology in human health care. Nanomedicine. 3:20-31.

7. Ai, H., Bu, Y. and Han, K. (2003). Glycine-Zn+/Zn2+ and their hydrates: on the number of water molecules necessary to stabilize the zwitterionic glycine- $\mathrm{Zn}+/ \mathrm{Zn} 2+$ over the nonzwitterionic ones. J. Chem. Phys. 118:10973-85.

8. Liu, S. Tian, J. Wang, L. and Sun, X. (2011). Microwave-assisted rapid synthesis of Ag nanoparticles/ graphene nanosheet composites and their application for hydrogen peroxide detection. J. Nanopart Res 2011, 13:4539-4548.

9. Hirota, K., Sugimoto, M., Kato, M., Tsukagoshi, K., Tanigawa, T. and Sugimoto, H. (2010). Preparation of zinc oxide ceramics with a sustainable antibacterial activity under dark conditions. Ceramics Int. 36:497506.

10. Senthilkumar, S.R. and Sivakumar,T. (2014). Green tea (Camellia sinensis) facilitated synthesis of zinc oxide $(\mathrm{ZnO})$ nanoparticles and studies on their antibacterial activities. International Journal of Pharmacy and Pharmaceutical Sciences.Vol 6, Issue 6.

11.Cataldo, F. (2014). Green synthesis of silver nanoparticales by the action of black or green tae infusions on silver ions Eur. Chem. Bull. 3 280-289.

12.Sahu, B.K. (2013). Antimicrobial properties of Aerial Part of Sesbaniagrandiflora (Linn.), The Pharmaceutical College Barpali, India.

13. Prasad, D., Girija, C.R., Reddy, J. A., Nagabhushana, B.M., Nagabhushana, Venkatesha ,T.V. and Arun Kumar, S.T. (2014 ). A Study on the Antibacterial Activity of Zno Nanoparticles Prepared By Combustion Method against E. coli. 2248-9622.

14 Abdelmonem, A.M and Amin, R.M. (2014). Rapid Green Synthesis of metal nanoparticles using pomegranate polyphenols, Int. J. Sci. Basic Appl. Res. 15 57e65.

15. Podrezora, L.V., Porro, S., Cauda,V., Fontana, M. and Cicero, G. (2013). Comparison between ZnO nanowires grown between chemical vapor deposition and hydrothermal synthesis, App. Phys. A 113, $623 \mathrm{e} 632$

16.Yousef, J.M. and Danial, E.M. (2012). In vitro antibacterial activity and minimum inhibitory concentration of zinc oxide and nanoparticle zinc oxide against pathogenic strains, J. Health Sci. 4,38e 42.

17. Cataldo, F. (2014). Green synthesis of silver nanoparticales by the action of black or green tae infusions on silver ions Eur. Chem. Bull. 3 280-289.

18. Iravani, S. (2011). Green synthesis of metal nanoparticles using plants. Green Chem. 13:2638-50.

19. Xu, H., Qu, F., Xu, H., Lai, W., Wang,Y.A., Aguilar, Z. P. and Wei, H. (2012). Role of reactive oxygen species in the antibacterial mechanism of silver Nanoparticles on Escherichia coli O157:H7, Biometals, 25:45-53.

20. Lin, Y-S., Tsai, Y-J., Tsay, J-S. and Lin, J-K. (2003). Factors affecting the levels of tea polyphenols and caffeine in tea leaves. Journal of Agricultural and Food Chemistry. 51. (7):1864-73.

21.Sawai, J. (2003). Quantitative evaluation of antibacterial activities of metallic oxide powders $(\mathrm{ZnO}, \mathrm{MgO}$ and $\mathrm{CaO}$ ) by conductimetric assay. J. Microbiol Methods. 54:177-82.

22. Umar, A., Rahman, M.M., Vaseem, M. and Hahn, Y.B. (2009). Ultra-sensitive cholesterol biosensor based on low-temperature grown $\mathrm{ZnO}$ nanoparticles. Electrochem Commun. 11:118-2.

23. Padmavathy, N. and Vijayaraghavan, R. (2008). Enhanced bioactivity of $\mathrm{ZnO}$ nanoparticles-an antimicrobial study. Sci Technol Adv Mater 2008; 9:035004, doi:10.1088/1468-6996/9/3/035004

24. Sawai, J. and Yoshikawa, T. (2004). Quantitative evaluation of antifungal activity of metallic oxide powders ( $\mathrm{MgO}, \mathrm{CaO}$ and $\mathrm{ZnO})$ by an indirect conductimetric assay. J Appl Microbiol. 96:803-9.

25. Jalal, R., Goharshadi, E.K., Abareshi, M., Moosavi, M., Yousefi, A. P. and Nancarrow, P. (2010). ZnO nanofluids: green synthesis, characterization, and antibacterial activity. Mater. Chem. Phys. 121(1). 198201.

26.Seil, J.T. and Webster, T.J. (2012). Antimicrobial applications of nanotechnology: methods and literature. Int. J. Nanomed. 7, 2767-2781.

27. Jin, T., Sun, D., Su, J.Y., Zhang, H. and Sue, H.J. (2009). Antimicrobial efficacy of zinc oxide quantum dots against Listeria monocytogenes, Salmonella enteritidis, and Escherichia coli O157:H7. J Food Sci 2 74:M46-52. 
28. Wahab, R., Siddiqui, M.A., Saquib, Q., Dwivedi, S., Ahmad, J., Musarrat, A.A., Al-Khedhairy, H. S. and Shin, H. S. (2014). ZnO nanoparticles induced oxidative stress and apoptosis in HepG2 and MCF-7 cancer cells and their antibacterial activity. Colloids Surf. B 117, 267-276 doi:10.1016/j.colsurfb. 2014. 02.038.

29. Stankovic, A., Dimitrijevic, S. and Uskokovic, D. (2013). Influence of size scale and morphology on antibacterial properties of $\mathrm{ZnO}$ powders hydrothermally synthesized using different surface stabilizing agents. Colloids Surf. B 102, 21-28.

30. Wu, J.M. (2015). Heterojunction nanowires of AgxZn1-xO-ZnO photocatalytic and antibacterial activities under visible-light and dark conditions. J. Phys. Chem. C 119(3), 1433-1441.

31.Tariq Jan, J.I., Ismail, M., Zakaullah, S.H., Naqvi, N. and Badshah, Sn. (2013). Doping induced enhancement in the activity of $\mathrm{ZnO}$ nanostructures against antibiotic resistant $S$. Aureus bacteria. Int. J. Nanomed. 8(1), 3679-3687. 